\title{
Preparation, Characterization, and Catalytic Activity of Tin (Antimony) Substituted and Lacunar Dawson Phosphotungstomolybdates for Synthesis of Adipic Acid
}

\author{
Mohamed Riad Guerroudj1,2, Leila Dermeche1,3*, Lynda Mouheb1,3, Tassadit Mazari1,3, \\ Siham Benadji ${ }^{1}$, Chérifa Rabia ${ }^{1}$
}

${ }^{1}$ Laboratoire de Chimie du Gaz Naturel, Faculté de Chimie, Université des Sciences et de la Technologie

Houari Boumediene (USTHB), BP 32, El-Alia, 16111 Bab-Ezzouar, Alger, Algeria

${ }^{2}$ Centre de Recherche Scientifique et Technique en Analyse Physico-chimique CRAPC, BP 384,

Zone Industrielle Bou-Ismail, RP 42004 Tipaza, Algeria

${ }_{3}^{3}$ Laboratoire de Recherche de Chimie Appliquée et de Génie Chimique, Hasnaoua I,

Université Mouloud Mammeri B.P.17 RP, 15000 Tizi-Ouzou, Algeria

Received: $6^{\text {th }}$ July 2018; Revised: 21st November 2018; Accepted: $4^{\text {th }}$ December 2018;

Available online: 30th April 2019; Published regularly: 1st August 2019

\begin{abstract}
Tin (antimony) substituted and lacunar Dawson phosphotungstomolybdates ( $\alpha 1-\mathrm{K}_{10} \mathrm{P}_{2} \mathrm{~W}_{12} \mathrm{Mo}_{5} \square \mathrm{O}_{61}$, $\alpha 1$ $\mathrm{K}_{8} \mathrm{P}_{2} \mathrm{~W}_{12} \mathrm{Mo5}_{5} \mathrm{SnO}_{61}$ and $\alpha-\mathrm{Cs}_{4} \mathrm{SnP}_{2} \mathrm{~W}_{12} \mathrm{Mo}_{6} \mathrm{O}_{62}$, and $\alpha-\mathrm{Cs}_{3} \mathrm{SbP}_{2} \mathrm{~W}_{12} \mathrm{Mo}_{6} \mathrm{O}_{62}$ ) were synthesized and characterized by Fourier Transform Infra Red (FTIR), nuclear magnetic resonance (31P NMR), Visible Ultra Violet (UV-Vis) spectroscopy, and X-ray diffraction (XRD). Their catalytic properties were examined in the oxidation reaction of cyclohexanone at $90{ }^{\circ} \mathrm{C}$ and that of cyclohexene at $70{ }^{\circ} \mathrm{C}$ to adipic acid (AA), in presence of hydrogen peroxide and in free solvent. The effects of catalyst/substrate molar ratios, hydrogene peroxide flow rate, heteropolysalt composition, and cyclohexanol addition on AA yields were studied. The $\mathrm{Cs}_{4} \mathrm{SnP}_{2} \mathrm{~W}_{12} \mathrm{Mo}_{6} \mathrm{O}_{62}$ (the most efficient) led to $61 \%$ of AA yield from the cyclohexanone oxidation using a catalyst/substrate molar ratio of $13.3 \times 10^{-4}, \mathrm{H}_{2} \mathrm{O}_{2}$ flow rate of $0.5 \mathrm{~mL} / \mathrm{h}$, and a reaction time of $20 \mathrm{~h}$. Copyright (C) 2019 BCREC Group. All rights reserved
\end{abstract}

Keywords: Dawson; polyoxometalate; adipic acid; cyclohexanone; cyclohexene

How to Cite: Guerroudj, M.R., Dermeche, L., Mouheb, L., Mazari, T., Benadji, S., Rabia, C. (2019). Preparation, Characterization, and Catalytic Activity of Tin (Antimony) Substituted and Lacunar Dawson Phosphotungstomolybdates for Synthesis of Adipic Acid. Bulletin of Chemical Reaction Engineering \& Catalysis, 14 (2): 283-293 (doi:10.9767/bcrec.14.2.2905.283-293)

Permalink/DOI: https://doi.org/10.9767/bcrec.14.2.2905.283-293

\section{Introduction}

Polyoxometalates (POMs) are metal-oxide clusters, with great diversity in framework. The most studied in field catalysis, are the Keggintype followed by Dawson-type POMs [1-8]. These latter, although their synthesis is difficult, present many advantages as a more num-

*Corresponding Author.

E-mail: der_lila@yahoo.fr(L. Dermeche) ber of transition metal atoms (18 against 12 by polyanion) giving thus a more great choice in the polyanion composition variation and therefore in the modification of their acid and oxidative properties. Dawson-type POMs were shown to be effective in various oxidation processes as methanol oxidation [8], 3,4-dihydropyrimidinones synthesis [9], epoxidation of cyclooctene and that of cyclohexene [10], phenol hydroxylation [7], isobutane oxidehydrogenation 
to isobutene [5], adipic acid synthesis [11,12] and other catalytic applications [13]. In this work, we were interested in the Dawson-type POMs application as catalysts, in the cyclohexanone oxidation to adipic acid (AA), important product principally used in nylon synthesis. In industrial process, AA is commonly prepared by oxidation of a mixture of cyclohexanone and cyclohexanol (known as KA oil) using nitric acid in presence of $\mathrm{Cu} / \mathrm{V}$ catalyst [14-16]. KA-oil was obtained from cyclohexane oxidation in the presence of air. However, the reduction of $\mathrm{HNO}_{3}$ generates a large amount of greenhouse gases. Among them, $\mathrm{N}_{2} \mathrm{O}$ is the most dangerous [17]. An alternative to this process was already the subject of several works.

The used oxidants are molecular oxygen, air, and particularly hydrogen peroxide [18-25]. This latter is easier to handle and in addition, its reduction leads only to the water formation. The AA synthesis using the hydrogen peroxide was examined with different catalysts based on $\mathrm{Ni}, \mathrm{Co}, \mathrm{Mn}, \mathrm{Mo}$, and $\mathrm{W}[12,18-26]$. In recent works, we have shown that the introduction of elements, such as: tin and antimony, into Keggin-type POMs improves the catalytic performance of the solid. The AA yields of ca. $60 \%$ were achieved with $\mathrm{NH}_{4} \mathrm{SnPMo}_{12} \mathrm{O}_{40}$ [22]. On the other hand, we have also demonstrated the efficiency of Dawson-type POMs of composition $\mathrm{K}_{6} \mathrm{P}_{2} \mathrm{Mo}_{\mathrm{x}} \mathrm{W}_{18-\mathrm{x}} \mathrm{O}_{62}(\mathrm{x}=5,6)$ in AA synthesis [12]. So, the objective of this work is to introduce tin and antimony into this type of material. Dawson-type POMs examined in the AA synthesis have formula of $\alpha-\mathrm{K}_{6} \mathrm{P}_{2} \mathrm{~W}_{18} \mathrm{O}_{62}, \quad \alpha$ $\mathrm{K}_{6} \mathrm{P}_{2} \mathrm{Mo}_{6} \mathrm{~W}_{12} \mathrm{O}_{62}, \quad \alpha-\mathrm{H}_{6} \mathrm{P}_{2} \mathrm{~W}_{12} \mathrm{Mo}_{6} \mathrm{O}_{62}, \quad \alpha 1-$ $\mathrm{K}_{10} \mathrm{P}_{2} \mathrm{~W}_{12} \mathrm{Mo}_{5} \square \mathrm{O}_{61}, \quad \alpha 1-\mathrm{K}_{8} \mathrm{P}_{2} \mathrm{~W}_{12} \mathrm{Mo}_{5} \mathrm{SnO}_{61}, \quad \alpha$ $\mathrm{Cs}_{4} \mathrm{SnP}_{2} \mathrm{~W}_{12} \mathrm{Mo}_{6} \mathrm{O}_{62}$, and $\alpha-\mathrm{Cs}_{3} \mathrm{SbP}_{2} \mathrm{~W}_{12} \mathrm{Mo}_{6} \mathrm{O}_{62}$. The AA synthesis was carried out from liquidphase oxidation of cyclohexanone and/or cyclohexanol and cyclohexene in the presence of hydrogen peroxide (30 \%) without solvent, acidic additives, and phase transfer agents. The method is based on that proposed by Nomiya et al. [28]. POMs were characterized by FT-IR, ${ }^{31} \mathrm{P}$ NMR, UV-Vis spectroscopy, and XRD.

\section{Materials and Method}

\subsection{POM Synthesis}

The $\quad \alpha-\mathrm{K}_{6} \mathrm{P}_{2} \mathrm{~W}_{18} \mathrm{O}_{62}, \quad 1,4,9,10,15,16-$ $\mathrm{K}_{6} \mathrm{P}_{2} \mathrm{~W}_{12} \mathrm{Mo}_{6} \mathrm{O}_{62}, 1,4,9,10,15,16-\mathrm{H}_{6} \mathrm{P}_{2} \mathrm{~W}_{12} \mathrm{Mo}_{6} \mathrm{O}_{62}$, $1,9,10,15,16-4-\mathrm{K}_{10} \mathrm{P}_{2} \mathrm{~W}_{12} \mathrm{M}_{5} \square \mathrm{O}_{61}$, and $1,9,10,15,16-4-\mathrm{K}_{8} \mathrm{P}_{2} \mathrm{~W}_{12} \mathrm{Mo}_{5} \mathrm{SnO}_{61}$ (noted $\alpha$ $\mathrm{P}_{2} \mathrm{~W}_{18}, \quad \alpha-\mathrm{P}_{2} \mathrm{~W}_{12} \mathrm{Mo}_{6}, \quad \alpha-\mathrm{H}_{6} \mathrm{P}_{2} \mathrm{~W}_{12} \mathrm{Mo}_{6}, \quad \alpha 1-$ $\mathrm{P}_{2} \mathrm{~W}_{12} \mathrm{Mo}_{5} \square$, and $\left.\alpha 1-\mathrm{P}_{2} \mathrm{~W}_{12} \mathrm{Mo5}_{5} \mathrm{Sn}\right)$ were synthesized according to established procedures [2833]. The $\alpha-\mathrm{P}_{2} \mathrm{~W}_{12} \mathrm{M}_{6}$ and $\alpha 1-\mathrm{P}_{2} \mathrm{~W}_{12} \mathrm{Mo}_{5} \square$ were obtained from hexavacant anion $\left[\mathrm{H}_{2} \mathrm{P}_{2} \mathrm{~W}_{12} \square_{6} \mathrm{O}_{48}\right]^{12-}$ according to the method described by Contant [30] and Randall [34]. Figure 1 illustrates successive steps involved in synthesis of W/Mo and W/Mo/Sn Dawson mixed heteropolyanions and Dawson polyhe-
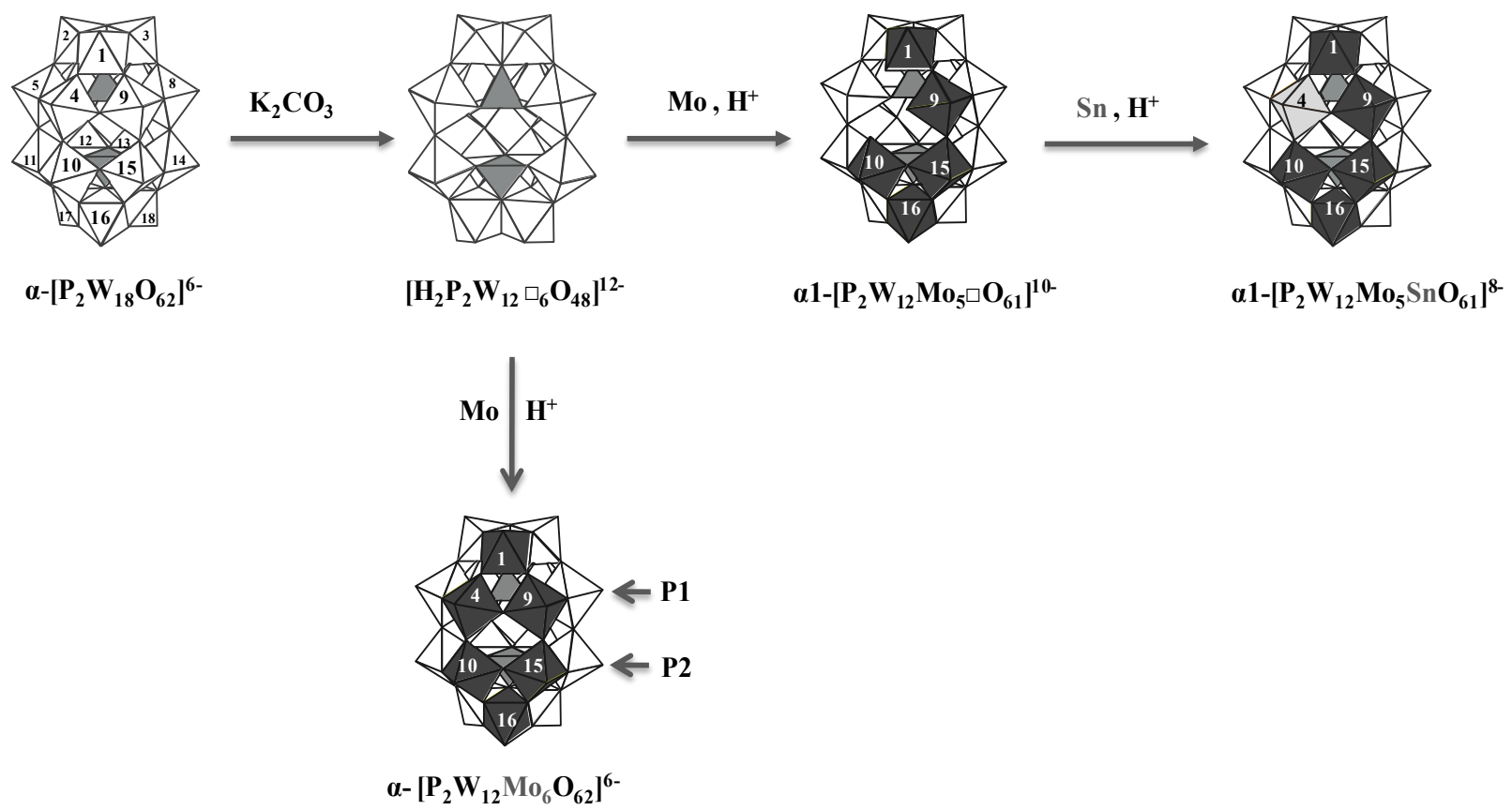

Figure 1. Successive steps of W/Mo and W/Mo/Sn mixed Dawson heteropolyanion, notation, and Dawson polyhedral representation with a numbering of the metallic atoms according to IUPAC recommendations 
dral representation with a numbering of the metallic atoms according to IUPAC recommendations. In Dawson heteropolyanion, two types of clusters are present: two terminal trimetallic groups $\mathrm{M}_{3} \mathrm{O}_{13}$ (numbers 1-3 and 16-18) and six bimetallic groups $\mathrm{M}_{2} \mathrm{O}_{10}$ (numbers 4 to 15 ) arranged in a double crown $[12,28]$.

The mixed cesium salts, $\mathrm{Cs}_{4} \mathrm{SnP}_{2} \mathrm{~W}_{12} \mathrm{Mo}_{6} \mathrm{O}_{62}$ and $\mathrm{Cs}_{3} \mathrm{SbP}_{2} \mathrm{~W}_{12} \mathrm{Mo}_{6} \mathrm{O}_{62}$, were prepared by precipitation from $\alpha-\mathrm{H}_{6} \mathrm{P}_{2} \mathrm{~W}_{12} \mathrm{Mo} 6, \mathrm{SnCl}_{2}$ or $\mathrm{SbCl}_{3}$, and $\mathrm{CsCl}$ according with the stoichiometric ratios (Equations (1) and (2)). $\mathrm{Cs}_{4} \mathrm{SnP}_{2} \mathrm{~W}_{12} \mathrm{Mo}_{6}$ is dark blue and the $\mathrm{Cs}_{3} \mathrm{SbP}_{2} \mathrm{~W}_{12} \mathrm{Mo}_{6}$ is green.

$$
\begin{array}{r}
\mathrm{H}_{6} \mathrm{P}_{2} \mathrm{~W}_{12} \mathrm{Mo}_{6} \mathrm{O}_{62}+\mathrm{SnCl}_{2}+4 \mathrm{CsCl} \rightarrow \\
\mathrm{Cs}_{4} \mathrm{SnP}_{2} \mathrm{~W}_{12} \mathrm{Mo}_{6} \mathrm{O}_{62}+6 \mathrm{HCl} \\
\mathrm{H}_{6} \mathrm{P}_{2} \mathrm{~W}_{12} \mathrm{Mo}_{6} \mathrm{O}_{62}+\mathrm{SbCl}_{3}+3 \mathrm{CsCl} \rightarrow \\
\mathrm{Cs}_{3} \mathrm{SbP}_{2} \mathrm{~W}_{12} \mathrm{Mo}_{6} \mathrm{O}_{62}+6 \mathrm{HCl}
\end{array}
$$

\subsection{Characterization}

Infrared spectra were recorded on the 4000 $400 \mathrm{~cm}^{-1}$ range on Bruker IFS 66 FT-IR spectrometer using samples prepared as $\mathrm{KBr}$ disks. ${ }^{31} \mathrm{P}$ MAS NMR spectra were measured at room temperature on Bruker Avance 400 spectrometer. The $85 \% \mathrm{H}_{3} \mathrm{PO}_{4}$ was used as an external reference. UV-Vis Diffuse Reflectance spectra were recorded in the $800-200 \mathrm{~nm}$ region on Specord 210 Plus Analytic Jena spectrometer equipped with a polytetrafluoroethylene (PTFE) integration sphere. PTFE was used as a reference. X-ray Diffraction analysis was obtained on a BRUKER D8 ADVANCE X-ray diffractometer using a $\mathrm{Cu}-\mathrm{K} \alpha(k=1.54178 \AA$ A $) \mathrm{ra}$ diation, in the range of $2 \theta=5-60^{\circ}$ at a rate of $0.02^{\circ} \cdot \mathrm{s}^{-1}$.

\subsection{Catalytic Methods}

The synthesis method is based on that described in the literature [27]. The liquid-phase oxidation was carried out at $90^{\circ} \mathrm{C}$ in the case of cyclohexanone (-one) and at $70^{\circ} \mathrm{C}$ in the case of cyclohexene (-ene), using a $100 \mathrm{~mL}$ roundbottomed flask equipped with a magnetic stirring bar and a reflux condenser. The whole is stirred at $1000 \mathrm{rpm}$ for $20 \mathrm{~h}$ reaction time. The reaction mixture is constituted by a calculated amount of POM catalyst and substrate. Hydrogen peroxide $(30 \%)$ is added drop wise whenever the POM is reduced. The state of the latter is visualized by the presence of a blue color corresponding to $\mathrm{Mo}(\mathrm{V})$ atoms. After adding of $\mathrm{H}_{2} \mathrm{O}_{2}$, the catalyst shows a color change from blue to yellow, color characteristic of $\mathrm{Mo}(\mathrm{VI})$. It should be pointed out that only two Mo(VI) per Keggin anion can undergo a reduction at a time and the resultant homogeneous mixture was cooled at $0{ }^{\circ} \mathrm{C}$ overnight. The AA, one of oxidation products, was isolated as white crystals and identified by FT-IR and ${ }^{1} \mathrm{H}-\mathrm{NMR}$ spectroscopy and melting point $\left(\sim 151{ }^{\circ} \mathrm{C}\right)$. The AA yield is given by the following relationship: AA yield $(\%)=$ AA recovered mass $\times 100 /$ theoretical AA mass.

\section{Results and Discussion}

\subsection{Catalysts Characterization}

Figure 2 shows FT-IR spectra of the Dawson potassium salts $\left(\alpha-\mathrm{P}_{2} \mathrm{~W}_{18}, \quad \alpha-\mathrm{P}_{2} \mathrm{~W}_{12} \mathrm{Mo}_{6}\right.$, $\alpha 1-\mathrm{P}_{2} \mathrm{~W}_{12} \mathrm{Mo}_{5} \square$ and $\left.\alpha 1-\mathrm{P}_{2} \mathrm{~W}_{12} \mathrm{Mo}_{5} \mathrm{Sn}\right)$, heteropolyacid $\alpha-\mathrm{H}_{6} \mathrm{P}_{2} \mathrm{~W}_{12} \mathrm{Mo}_{6}$ and cesium salts ( $\mathrm{Cs}_{4} \mathrm{SnP}_{2} \mathrm{~W}_{12} \mathrm{Mo}_{6}$ and $\left.\mathrm{Cs}_{3} \mathrm{SbP}_{2} \mathrm{~W}_{12} \mathrm{Mo}_{6}\right)$. Dawson anion characteristic vibration bands were observed in the low wave number region (500-100
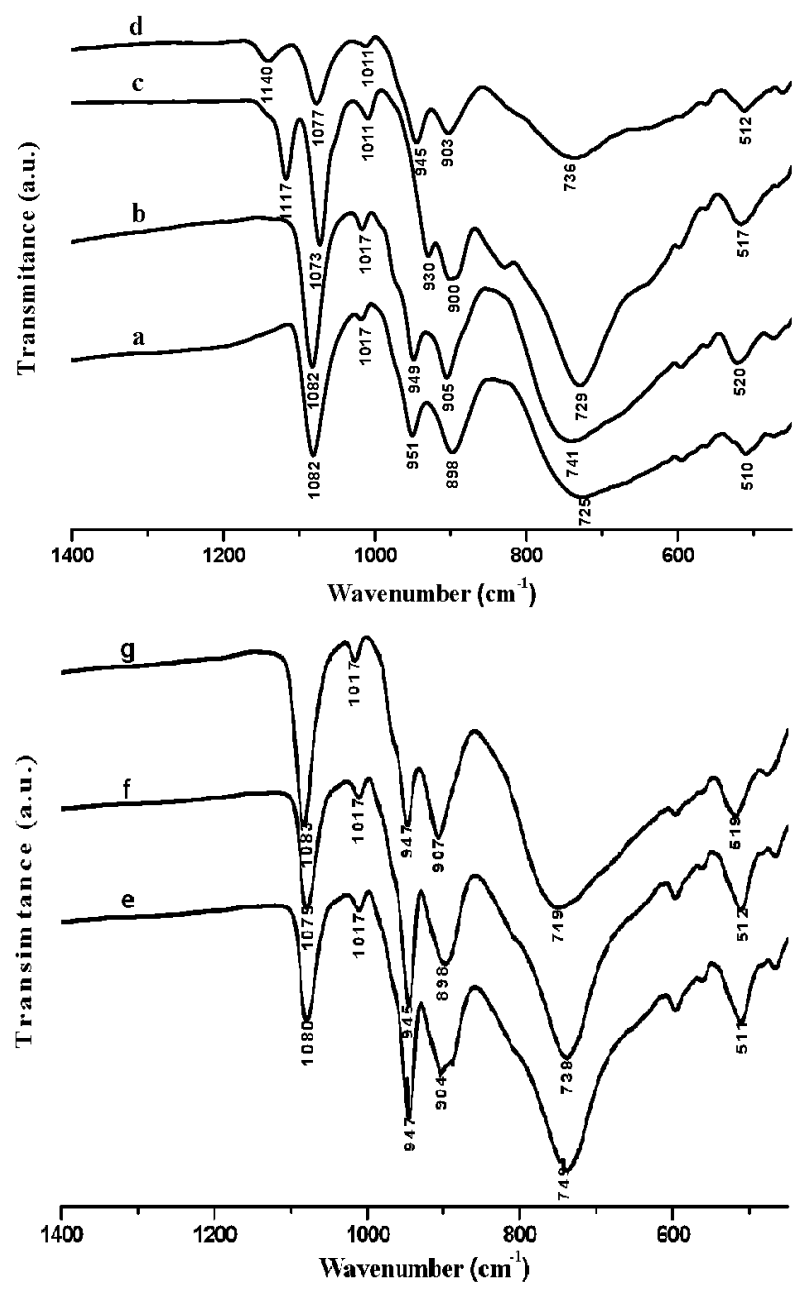

Figure 2. FT-IR spectra of $\alpha-\mathrm{P}_{2} \mathrm{~W}_{18}(\mathrm{a}), \alpha-$ $\mathrm{P}_{2} \mathrm{~W}_{12} \mathrm{Mo}_{6}$ (b), $\alpha 1-\mathrm{P}_{2} \mathrm{~W}_{12} \mathrm{Mo}_{5} \square$ (c), $\alpha 1-\mathrm{P}_{2} \mathrm{~W}_{12} \mathrm{Mo}_{5} \mathrm{Sn}$ (d), $\quad \alpha-\mathrm{H}_{6} \mathrm{P}_{2} \mathrm{~W}_{12} \mathrm{Mo}_{6}(\mathrm{e}), \mathrm{Cs}_{4} \mathrm{SnP}_{2} \mathrm{~W}_{12} \mathrm{Mo}_{6}$ (f), and $\mathrm{Cs}_{3} \mathrm{SbP}_{2} \mathrm{~W}_{12} \mathrm{Mo}_{6}(\mathrm{~g})$ 
$\mathrm{cm}^{-1}$ ). The metal-oxygen vibration bands corresponding to inter group $\mathrm{M}-\mathrm{O}_{\mathrm{b}}-\mathrm{M}$ and the intragroup $\mathrm{M}-\mathrm{O}_{\mathrm{c}}-\mathrm{M}$ appear at $898-907 \mathrm{~cm}^{-1}$ and $725-749 \mathrm{~cm}^{-1}$, respectively. The elongation of $\mathrm{M}=\mathrm{O}_{\mathrm{d}}$ band appear at $930-951 \mathrm{~cm}^{-1}$ range. In the Dawson anion, the phosphorus-oxygen vibration band is very sensitive to its environment. An intense vibration band appears around $1073-1083 \mathrm{~cm}^{-1}$ assigned to the junction phosphorus-bimetallic group $\mathrm{M}_{2} \mathrm{O}_{10}$ (noted (P$\mathrm{Oa})_{\mathrm{b}}$ ) and another around 1011-1017 $\mathrm{cm}^{-1}$ of low intensity attributed to the junction phosphorus- trimetallic group $\mathrm{M}_{3} \mathrm{O}_{13}$ (noted $\left.(\mathrm{P}-\mathrm{Oa})_{\mathrm{t}}\right)$. FT-IR band observed around $510-520 \mathrm{~cm}^{-1}$ is attributed to $\delta(\mathrm{P}-\mathrm{O})$ vibration. These results are in agreement with those of the literature $[32,33,35]$. In addition, in the cases of $\alpha 1$ $\mathrm{P}_{2} \mathrm{~W}_{12} \mathrm{Mo}_{5} \square$ and $\alpha 1-\mathrm{P}_{2} \mathrm{~W}_{12} \mathrm{Mo}_{5} \mathrm{Sn}$, vibration bands were observed at 1117 and $1140 \mathrm{~cm}^{-1}$, respectively, resulting of the local symmetry decrease attributed to the vacancy presence and to the Sn atom introduction in this vacancy situated in bimetallic group (number 4 as seen in Figure 1).
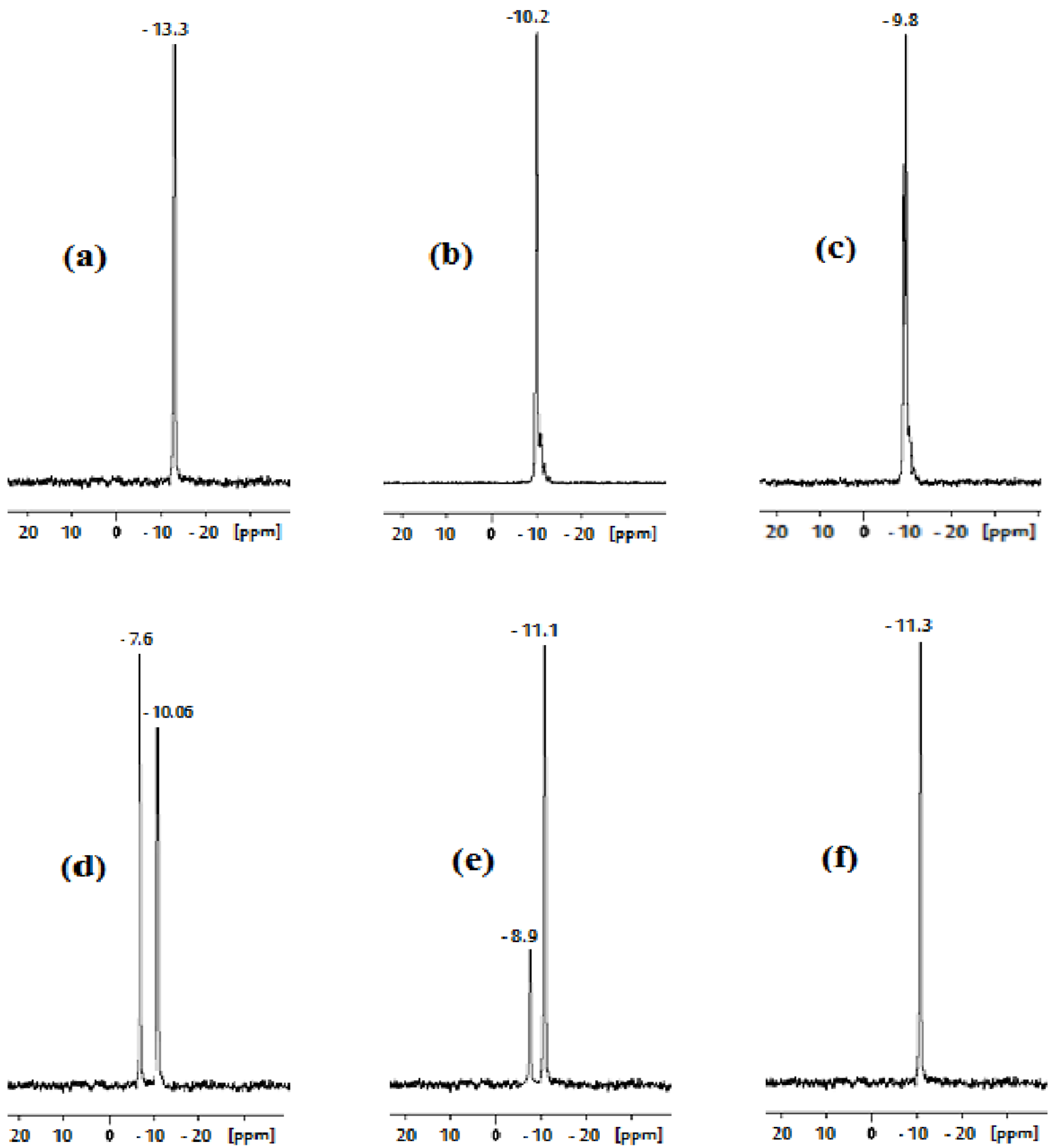

Figure 3. ${ }^{31} \mathrm{P}$ NMR spectrum of $\alpha-\mathrm{P}_{2} \mathrm{~W}_{18}$ (a), $\alpha-\mathrm{P}_{2} \mathrm{~W}_{12} \mathrm{Mo6}$ (b), $\alpha-\mathrm{H}_{6} \mathrm{P}_{2} \mathrm{~W}_{12} \mathrm{Mo}_{6}(\mathrm{c}), \alpha 1-\mathrm{P}_{2} \mathrm{~W}_{12} \mathrm{Mo}_{5} \square$ (d), $\alpha 1-$ $\mathrm{P}_{2} \mathrm{~W}_{12} \mathrm{Mo5} \mathrm{Sn}(\mathrm{e})$ and $\mathrm{Cs}_{4} \mathrm{SnP}_{2} \mathrm{~W}_{12} \mathrm{Mo}_{6}$ (f) 
The ${ }^{31 P}$ NMR chemical shifts data of the Dawson POMs are presented in Figure 3. Only single resonance peak recorded at $-9.8,-13.3,-$ 10.2 and $-11.3 \mathrm{ppm}$ was observed for $\alpha-\mathrm{H}_{6} \mathrm{P}_{2} \mathrm{~W}_{12} \mathrm{Mo6}, \quad \alpha-\mathrm{P}_{2} \mathrm{~W}_{18} \mathrm{O}_{62}, \quad \alpha-\mathrm{P}_{2} \mathrm{~W}_{12} \mathrm{Mo}_{0}$, and $\mathrm{Cs}_{4} \mathrm{SnP}_{2} \mathrm{~W}_{12} \mathrm{Mo}_{6}$, respectively, showing that the two half-anions of the Dawson structure are identical. Therefore, these results evidenced the purity of prepared Dawson POMs. The presence of the vacancy in $\alpha 1-\mathrm{P}_{2} \mathrm{~W}_{12} \mathrm{Mo}_{5} \square$ and the $\mathrm{Sn}$ atom insertion in the case of $\alpha 1-\mathrm{P}_{2} \mathrm{~W}_{12} \mathrm{Mo}_{5} \mathrm{Sn}$, were highlighted by the two signals observed at -7.6 and $-10.06 \mathrm{ppm}$ as well as -8.9 and $-11.1 \mathrm{ppm}$, respectively, results according with those observed in FT-IR spectroscopy. For $\mathrm{Cs}_{3} \mathrm{SbP}_{2} \mathrm{~W}_{12} \mathrm{Mo}_{6}$, no signal observed, lied probably to the antimony element paramagnetic.

The UV-Vis spectra of $\alpha-\mathrm{P}_{2} \mathrm{~W}_{18}$ (a), $\alpha-\mathrm{P}_{2} \mathrm{~W}_{12} \mathrm{Mo}_{6} \quad$ (b), $\quad \alpha 1-\mathrm{P}_{2} \mathrm{~W}_{12} \mathrm{Mo}_{5} \square \quad$ (c), $\quad \alpha 1-$ $\mathrm{P}_{2} \mathrm{~W}_{12} \mathrm{M}_{5} \mathrm{Sn}$, (d) $\mathrm{C}_{4} \mathrm{SnP}_{2} \mathrm{~W}_{12} \mathrm{Mo}_{6}$ (e), and $\mathrm{Cs}_{3} \mathrm{SbP}_{2} \mathrm{~W}_{12} \mathrm{Mo}_{6}$ (f) (Figure 4) show a large band
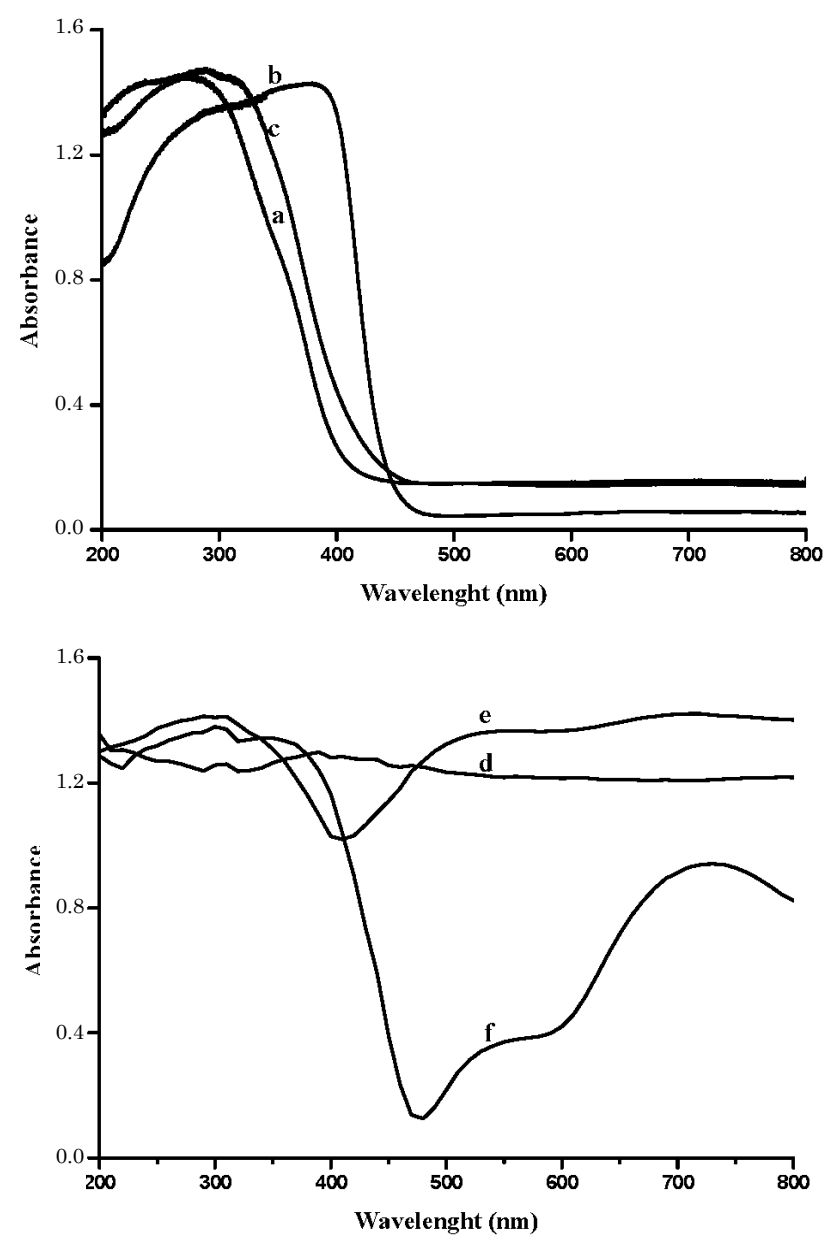

Figure 4. UV-vis/diffuse spectra of $\alpha-\mathrm{P}_{2} \mathrm{~W}_{18}(\mathrm{a})$, $\alpha-\mathrm{P}_{2} \mathrm{~W}_{12} \mathrm{Mo}_{6} \quad$ (b), $\quad \alpha 1-\mathrm{P}_{2} \mathrm{~W}_{12} \mathrm{Mo}_{5} \square \quad$ (c), $\alpha 1-\mathrm{P}_{2} \mathrm{~W}_{12} \mathrm{Mo}_{5} \mathrm{Sn} \quad(\mathrm{d}), \quad \mathrm{Cs}_{4} \mathrm{SnP}_{2} \mathrm{~W}_{12} \mathrm{Mo}_{6}$ (e), and $\mathrm{Cs}_{3} \mathrm{SbP}_{2} \mathrm{~W}_{12} \mathrm{Mo}_{6}$ (f) in $200-500 \mathrm{~nm}$ wavelengths domain assigned to oxygen-metal charge transfer (LMCT), corresponding to the oxidation state VI of metal [8,36-41]. In the case of substituted POMs, the introduction of tin and antimony led to the appearance to another LMCT band above 700 $\mathrm{nm}$ that can attributed to molybdenum atoms in an oxidation state V. This observation was already reported in the case of substituted Keggin-type POMs [37-42]. The intensity of this band increases following the sequence $\mathrm{Cs}_{4} \mathrm{SnP}_{2} \mathrm{~W}_{12} \mathrm{Mo}_{6}>\alpha 1-\mathrm{P}_{2} \mathrm{~W}_{12} \mathrm{Mo}_{5} \mathrm{Sn}>$ $\mathrm{Cs}_{3} \mathrm{SbP}_{2} \mathrm{~W}_{12} \mathrm{Mo}_{6}$. It was also reported that the Mo(VI) reduced amount increases with the band intensity $[37,38]$. These observations suggest a partial reduction of POMs confirmed by the observed blue color during their preparation. This suggests that an electron exchange takes place between $\mathrm{Sn}(\mathrm{II})$ or $\mathrm{Sb}(\mathrm{III})$ and Mo(VI) (Equations (3) and (4)).

$$
\begin{array}{ll}
\mathrm{Sn}^{\mathrm{II}}+2 \mathrm{MoVI}^{\mathrm{VI}} & \leftrightarrow \mathrm{Sn}^{\mathrm{IV}}+2 \mathrm{MoV} \\
\mathrm{Sb}^{\mathrm{III}}+2 \mathrm{MoVI}^{\mathrm{VI}} & \leftrightarrow \mathrm{Sb}^{2}+2 \mathrm{MoV}^{2}
\end{array}
$$

Figure 5 shows the X-ray patterns of prepared salts. The $\mathrm{XR}$ pattern of $\mathrm{K}_{6} \mathrm{P}_{2} \mathrm{~W}_{18}$ is characteristic of a triclinic system, with the following parameters: $a=12.8600 \AA, b=14.8300 \AA$, $c$ $=22.3400 \AA, \alpha=94.400^{\circ}, \beta=116.870^{\circ}$ and $\gamma=$ $115.600^{\circ}$ and spacial group P -1 (2), according to the literature data [43-45]. The $\alpha-\mathrm{K}_{6} \mathrm{P}_{2} \mathrm{~W}_{12} \mathrm{Mo}_{6} \mathrm{O}_{62}$ (Figure 5b) presents also $\mathrm{X}$ ray pattern characteristic of a triclinic system. X-ray diffraction patterns of $\alpha 1-\mathrm{P}_{2} \mathrm{~W}_{12} \mathrm{Mo}_{5} \mathrm{Sn}$ (Figure $5 \mathrm{~d}$ ) and $\mathrm{Cs}_{4} \mathrm{SnP}_{2} \mathrm{~W}_{12} \mathrm{Mo}_{6}$ (Figure 5e) are similar and appear to crystallize in a different system from the triclinic system. It is the same for $\alpha 1-\mathrm{P}_{2} \mathrm{~W}_{12} \mathrm{Mo}_{5} \square$ (Figure 5c) and

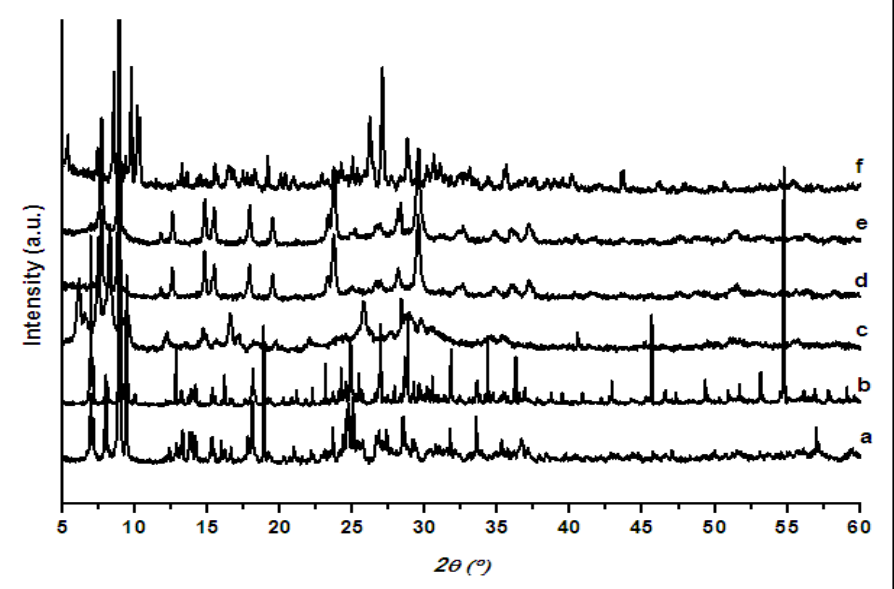

Figure 5. XRD patterns of $\alpha-\mathrm{P}_{2} \mathrm{~W}_{18}(\mathrm{a}), \alpha-\mathrm{P}_{2} \mathrm{~W}_{12} \mathrm{Mo} 6$ (b), $\alpha 1-\mathrm{P}_{2} \mathrm{~W}_{12} \mathrm{Mo5}^{\square} \quad$ (c), $\quad \alpha 1-\mathrm{P}_{2} \mathrm{~W}_{12} \mathrm{Mo}_{5} \mathrm{Sn} \quad$ (d), $\mathrm{Cs}_{4} \mathrm{SnP}_{2} \mathrm{~W}_{12} \mathrm{Mo}_{6}(\mathrm{e})$, and $\mathrm{Cs}_{3} \mathrm{SbP}_{2} \mathrm{~W}_{12} \mathrm{Mo}_{6}$ (f) 
$\mathrm{Cs}_{3} \mathrm{SbP}_{2} \mathrm{~W}_{12} \mathrm{Mo}_{6}$ (Figure 5f) salts that present totally different X-ray patterns which would suggest that these two salts would also crystallize in different unidentified systems in the frame of this work. These results evidenced the influence of the composition of the POM on its crystalline structure.

\subsection{Catalytic Tests}

The catalytic performance of $\alpha-\mathrm{H}_{6} \mathrm{P}_{2} \mathrm{~W}_{12} \mathrm{Mo}$, $\alpha-\mathrm{P}_{2} \mathrm{~W}_{12} \mathrm{Mo}_{6}, \quad \alpha 1-\mathrm{P}_{2} \mathrm{~W}_{12} \mathrm{Mo}_{5}, \quad \alpha 1-\mathrm{P}_{2} \mathrm{~W}_{12} \mathrm{Mo}_{5} \mathrm{Sn}$, $\alpha-\mathrm{Cs}_{4} \mathrm{SnP}_{2} \mathrm{~W}_{12} \mathrm{Mo}_{6}$ and $\alpha-\mathrm{Cs}_{3} \mathrm{SbP}_{2} \mathrm{~W}_{12} \mathrm{Mo}_{6}$ Dawson type salts were examined in adipic acid synthesis from oxidation of both cyclohexanone at $90^{\circ} \mathrm{C}$ and cyclohexene at $70^{\circ} \mathrm{C}$, in the presence of hydrogen peroxide (30\%) and free solvent. It was showed that the substrate oxidation to AA did not take place in absence of catalyst and when the reaction was carried out in one pot (substrate + catalyst + hydrogen peroxide) [12, 20-22].

Catalytic tests were repeated three times in the case of cyclohexanone oxidation and twice

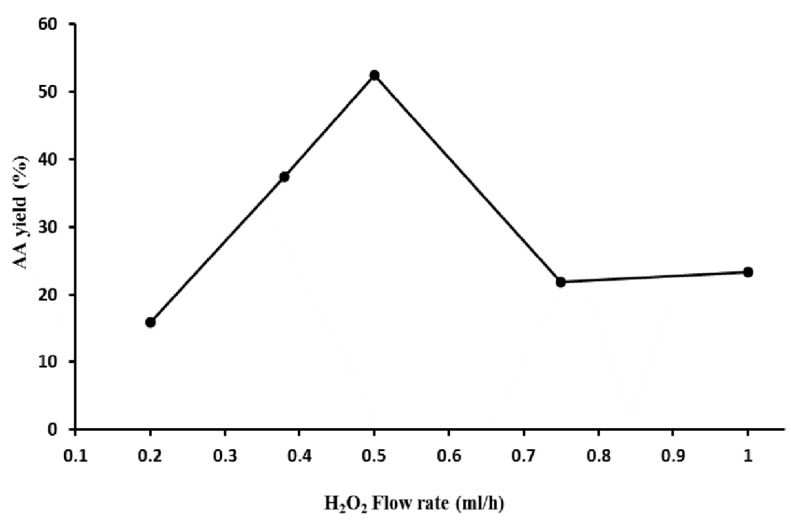

Figure 6. Adipic acid yields as function of hydrogen peroxide flow rate. Reaction parameters: Catalyst: $\quad \mathrm{Cs}_{4} \mathrm{SnP}_{2} \mathrm{~W}_{12} \mathrm{Mo}_{6}, \quad n_{\text {catalyst }} / n_{\text {-one: }}$ : $13.3 \times 10^{-4}$, reaction time: $20 \mathrm{~h}$; reaction temperature: $90{ }^{\circ} \mathrm{C}$, stirring: $1000 \mathrm{rpm}$ and $6 \mathrm{~mL}$ of $\mathrm{H}_{2} \mathrm{O}_{2}$ $30 \%$

Table 1. Reproducibility of the catalytic tests

\begin{tabular}{|c|c|c|c|c|c|c|c|}
\hline \multirow{2}{*}{ POMs } & \multicolumn{3}{|c|}{-one } & \multicolumn{2}{|c|}{-ol/-one } & \multicolumn{2}{|c|}{-ene } \\
\hline & Test 1 & Test 2 & Test 3 & Test 1 & Test 2 & Test 1 & Test 2 \\
\hline$\alpha-\mathrm{P}_{2} \mathrm{~W}_{12} \mathrm{Mo}_{6}$ & 46 & 39 & 41 & 46 & 47 & 21 & 20 \\
\hline$\alpha 1-\mathrm{P}_{2} \mathrm{~W}_{12} \mathrm{Mo5}_{\square} \square$ & 30 & 30 & 33 & 34 & 33 & 32 & 31 \\
\hline$\alpha 1-\mathrm{P}_{2} \mathrm{~W}_{12} \mathrm{Mo}_{5} \mathrm{Sn}$ & 33 & 32 & 33 & 17 & 17 & 23 & 23 \\
\hline $\mathrm{Cs}_{4} \mathrm{SnP}_{2} \mathrm{~W}_{12} \mathrm{Mo}_{6}$ & 61 & 59 & 59 & 27 & 21 & 11 & 11 \\
\hline $\mathrm{Cs}_{4} \mathrm{SbP}_{2} \mathrm{~W}_{12} \mathrm{Mo}_{6}$ & 52 & 48 & 49 & 37 & 34 & 29 & 30 \\
\hline
\end{tabular}

Reaction parameters: reaction time: $20 \mathrm{~h}$; reaction temperature: $\left(90{ }^{\circ} \mathrm{C}\right.$ for -one and $70^{\circ} \mathrm{C}$ for -ene); stirring: $1000 \mathrm{rpm}$; catalyst/substrate molar ratio: $13.3 \times 10^{-4}$ and $6 \mathrm{~mL}$ of $\mathrm{H}_{2} \mathrm{O}_{2}(30 \%)$ added with $0.5 \mathrm{~mL} / \mathrm{h}$ flow rate using manual mode in the case of the oxidation of alcohol/ketone and that of alkene to verify the reproducibility of the results. As shown by the results in the Table 1, the AA yields vary very little from one test to another, demonstrating the reproducibility of the catalytic test.

\subsubsection{Cyclohexanone oxidation}

In order to optimize the reaction parameters favoring to AA formation, the effect of catalyst/substrate molar ratio was examined with $\alpha-\mathrm{P}_{2} \mathrm{~W}_{12} \mathrm{Mo}_{6}$ catalyst. The cyclohexanone oxidation was carried out at $90{ }^{\circ} \mathrm{C}$, with a fixed flow rate of $\mathrm{H}_{2} \mathrm{O}_{2}$ of $1 \mathrm{~mL}$ every $150 \mathrm{~min}$, a reaction time of $20 \mathrm{~h}$ and a magnetic stirring of 1000 rpm. Table 2 shows an increase of AA yield from 12 to $39 \%$ with the increase of catalyst/cyclohexanone molar ratio (noted $n_{\text {catalyst }} / n$-one) from $4.0 \times 10^{-4}$ to $13.3 \times 10^{-4}$. Up to this latter value, AA yield decreases to $32 \%$. For all following catalytic experiments, the catalyst/-one molar ratio will fixed at $13.3 \times 10^{-4}$, corresponding to $90 \mathrm{mg}$ of catalyst and 15 mmol of substrate.

The effect of $\mathrm{H}_{2} \mathrm{O}_{2}$ flow rate on the adipic acid formation from cyclohexanone was exam-

Table 2. AA yields as function of catalyst/cyclohexanone molar ratio

\begin{tabular}{cc}
\hline$n_{\text {catalyst }} / n_{\text {-one }}\left(10^{4}\right)$ & AA Yield $(\%)$ \\
\hline 4.4 & 12 \\
6.7 & 14 \\
8.8 & 15 \\
9.2 & 30 \\
13.3 & 39 \\
18.5 & 32 \\
\hline
\end{tabular}

Reaction parameters: Catalyst: $\alpha-\mathrm{P}_{2} \mathrm{~W}_{12} \mathrm{Mo}_{6}$, reaction time: $20 \mathrm{~h}$, reaction temperature: $90^{\circ} \mathrm{C}$, stirring: $1000 \mathrm{rpm}$ and $\mathrm{H}_{2} \mathrm{O}_{2} 30 \%$ (8 mL, flow rate: 1 $\mathrm{mL} / 2 \mathrm{~h} 30$ ) 
ined in the presence $\mathrm{Cs}_{4} \mathrm{SnP}_{2} \mathrm{~W}_{12} \mathrm{Mo}_{6}$ catalyst. The oxidation reaction was conducted at $90{ }^{\circ} \mathrm{C}$ with a catalyst / cyclohexanone molar ratio of $13.3 \times 10^{-4}$, a reaction time of $20 \mathrm{~h}$ and a magnetic stirring of $1000 \mathrm{rpm}$. Hydrogen peroxide (30\%) was added during the reaction via a continual automatic mode using a device with a syringe pump that controls the $\mathrm{H}_{2} \mathrm{O}_{2}$ flow rate $(0.2-1.0 \mathrm{~mL} / \mathrm{h})$ and a manual mode that consists to add $\mathrm{H}_{2} \mathrm{O}_{2}$ by fraction of 0.5 or $1 \mathrm{~mL} / \mathrm{h}$. For both modes, the injected total $\mathrm{H}_{2} \mathrm{O}_{2}$ volume is of $6 \mathrm{~mL}$.

Figure 6 shows the obtained results from automatic mode. Two distinct domains were observed, with a maximum of AA yield (52 \%), obtained with a flow rate of $0.5 \mathrm{~mL} / \mathrm{h}$. From 0.2 to $0.5 \mathrm{~mL} / \mathrm{h}$, the AA yield increases from 16 to 52 $\%$ and from 0.5 to $1.0 \mathrm{~mL} / \mathrm{h}$, it decreases from 52 to $23 \%$. These results emphasize the hydrogen peroxide flow rate importance on the AA production. So, a low flow rate $(<0.5 \mathrm{~mL} / \mathrm{h})$, slows down the oxidation reaction of substrate and up to this value $(>0.5 \mathrm{~mL} / \mathrm{h})$, probably favoured the others oxidation products.

The results of the Table 3 confirms that a $\mathrm{H}_{2} \mathrm{O}_{2}$ flow rate of $0.5 \mathrm{~mL} / \mathrm{h}$ leads to best results regardless the used adding mode. So, when

Table 3. Adipic acid yields as function of hydrogen peroxide addition mode and $\mathrm{H}_{2} \mathrm{O}_{2}$ flow rate

\begin{tabular}{ccc}
\hline $\begin{array}{c}\mathrm{H}_{2} \mathrm{O}_{2} \text { Flow rate } \\
(\mathrm{mL} / \mathrm{h})\end{array}$ & Mode & AA yield (\%) \\
\hline \multirow{2}{*}{0.5} & Manual & 61 \\
& Automatic & 52 \\
\hline \multirow{3}{*}{1} & Manual & 42 \\
& Automatic & 23 \\
\hline
\end{tabular}

Reaction parameters: Catalyst: $\mathrm{Cs}_{4} \mathrm{SnP}_{2} \mathrm{~W}_{12} \mathrm{Mo}_{6}$, $n_{\text {catays }} / n_{\text {-one: }} 13.3 \times 10^{-4}$, reaction time: $20 \mathrm{~h}$; reaction temperature: $90{ }^{\circ} \mathrm{C}$; stirring: $1000 \mathrm{rpm}$ and $6 \mathrm{~mL}$ of $\mathrm{H}_{2} \mathrm{O}_{2} 30 \%$

Table 4. AA yields as function of reaction time over $\alpha-\mathrm{P}_{2} \mathrm{~W}_{12} \mathrm{Mo}_{6}$ and $\mathrm{Cs}_{4} \mathrm{SnP}_{2} \mathrm{~W}_{12} \mathrm{Mo}_{6}$ catalyst

\begin{tabular}{lcc}
\hline POMs & Time $(\mathrm{h})$ & AA yield (\%) \\
\hline \multirow{2}{*}{$\alpha-\mathrm{P}_{2} \mathrm{~W}_{12} \mathrm{Mo}_{6}$} & 10 & 29 \\
& 20 & 39 \\
\hline \multirow{2}{*}{$\mathrm{Cs}_{4} \mathrm{SnP}_{2} \mathrm{~W}_{12} \mathrm{Mo}_{6}$} & 10 & 28 \\
\end{tabular}

Reaction parameters: reaction temperature: $90{ }^{\circ} \mathrm{C}$, stirring: $1000 \mathrm{rpm}$; $n_{\text {catays }} / n_{\text {-one: }} 13.3 \times 10^{-4}$ and $6 \mathrm{~mL}$ of $\mathrm{H}_{2} \mathrm{O}_{2}(30 \%)$ added with $0.5 \mathrm{~mL} / \mathrm{h}$ flow rate using manual mode
$\mathrm{H}_{2} \mathrm{O}_{2}$ flow rate increases from 0.5 to $1 \mathrm{~mL} / \mathrm{h}$, AA yield decreases from 61 to $42 \%$ for manually adding and from 52 to $23 \%$ for automatically adding. Moreover, regardless $\mathrm{H}_{2} \mathrm{O}_{2}$ flow rate, the manual mode leads to the highest yields. For the following catalytic tests, a volume of 6 $\mathrm{mL}$ of $\mathrm{H}_{2} \mathrm{O}_{2}$ with a flow rate of $0.5 \mathrm{~mL} / \mathrm{h}$ and manual addition mode will used.

The time oxidation cyclohexanone effect on $\mathrm{AA}$ formation was examined on $\alpha-\mathrm{P}_{2} \mathrm{~W}_{12} \mathrm{Mo} 6$ and $\mathrm{Cs}_{4} \mathrm{SnP}_{2} \mathrm{~W}_{12} \mathrm{Mo}_{6}$. The oxidation reaction was conducted at $90{ }^{\circ} \mathrm{C}$ with a catalyst / cyclohexanone molar ratio of $13.3 \times 10^{-4}$, a magnetic stirring of $1000 \mathrm{rpm}$ and $6 \mathrm{~mL}$ of $\mathrm{H}_{2} \mathrm{O}_{2}(30 \%)$ added with $0.5 \mathrm{~mL} / \mathrm{h}$ flow rate using manual mode. Table 4 shows that after $10 \mathrm{~h}$ of reaction, the AA yields obtained with both $\mathrm{POM}_{\mathrm{s}}$ are similar (28-29\%), inferior to those obtained after $20 \mathrm{~h}$ of reaction (39-61 \%) suggesting an active site increase with the reaction time, favoring thus, the AA formation. Whereas, the AA yield increase is more important in the case of $\mathrm{Cs}_{4} \mathrm{SnP}_{2} \mathrm{~W}_{12} \mathrm{Mo}_{6}$ (from 28 to $61 \%$ ) compared to that observed with $\alpha-\mathrm{P}_{2} \mathrm{~W}_{12} \mathrm{Mo}_{6}$ (from 29 to 39 $\%)$. These results evidenced the tin action efficiency with the reaction time, on the catalytic performances, lied probably to the presence of redox couples $\mathrm{Mo}(\mathrm{VI}) / \mathrm{Mo}(\mathrm{V})$ and $\mathrm{Sn}(\mathrm{IV}) / \mathrm{Sn}(\mathrm{II})$. This would promote the oxidation either of the substrate or intermediate products to AA.

Table 5 shows the AA yield, obtained from cyclohexanone oxidation, as function of the Dawson-type POM composition. The catalytic performances were investigated under the optimized conditions. The proton total substitution of $\alpha-\mathrm{H}_{6} \mathrm{P}_{2} \mathrm{Mo}_{6} \mathrm{~W}_{12}$ heteropolyacid by the different elements (Cs, K, Sb, Sn) favour the adipic

Table 5. AA yields as function of POMs composition and substrate nature

\begin{tabular}{lcc}
\hline \multirow{2}{*}{\multicolumn{1}{c}{ Catalysts }} & \multicolumn{2}{c}{ AA Yields (\%) } \\
\cline { 2 - 3 } & -one & $\begin{array}{c}\text {-ol(50\%)/ } \\
\text {-one }(50 \%)\end{array}$ \\
\hline$\alpha-\mathrm{H}_{6} \mathrm{P}_{2} \mathrm{Mo}_{6} \mathrm{~W}_{12}$ & 14 & - \\
$\alpha-\mathrm{P}_{2} \mathrm{~W}_{12} \mathrm{Mo}_{6}$ & 46 & 47 \\
$\alpha 1-\mathrm{P}_{2} \mathrm{~W}_{12} \mathrm{Mo5} \square$ & 30 & 34 \\
$\alpha 1-\mathrm{P}_{2} \mathrm{~W}_{12} \mathrm{Mo}_{5} \mathrm{Sn}$ & 33 & 17 \\
$\mathrm{Cs}_{4} \mathrm{SnP}_{2} \mathrm{~W}_{12} \mathrm{Mo} 6$ & 61 & 27 \\
$\mathrm{Cs}_{3} \mathrm{SbP}_{2} \mathrm{~W}_{12} \mathrm{Mo}_{6}$ & 52 & 37 \\
\hline
\end{tabular}

Reaction parameters: reaction time: $20 \mathrm{~h}$; reaction temperature: $90{ }^{\circ} \mathrm{C}$; stirring: $1000 \mathrm{rpm}$; catalyst/ substrate molar ratio: $13.3 \times 10^{-4}$ and $6 \mathrm{~mL}$ of $\mathrm{H}_{2} \mathrm{O}_{2}(30 \%)$ added with $0.5 \mathrm{~mL} / \mathrm{h}$ flow rate using manual mode 
acid formation with yields of 30-61 \% against $14 \%$. In the case of the potassium based salts series, $\alpha-\mathrm{K}_{6} \mathrm{P}_{2} \mathrm{~W}_{12} \mathrm{Mo}_{6}$ is the more active toward AA formation with 46 against 30 and $33 \%$ of yields in the presence of $\mathrm{K}_{10} \mathrm{P}_{2} \mathrm{~W}_{12} \mathrm{Mo}_{5} \square$ and $\mathrm{K}_{8} \mathrm{P}_{2} \mathrm{~W}_{12} \mathrm{Mo5}_{5} \mathrm{Sn}$, respectively. With the caesium based salts series, higher AA yields were obtained (52-61 against 30-46\%). In this series, $\mathrm{Cs}_{4} \mathrm{SnP}_{2} \mathrm{~W}_{12} \mathrm{Mo}_{6}$ exhibits the best catalytic performance with an AA yield of $61 \%$, evidencing the importance of the role played by the tin as counter-ion, results in agreement with those obtained with the Keggin-type POMs [22].

The obtained AA yields (Table 5) from a quimolar mixture, cyclohexanol (-ol) and cyclohexanone (-one) are sensitive to POM composition. In the presence of $\alpha-\mathrm{P}_{2} \mathrm{~W}_{12} \mathrm{M}_{0}$ and $\alpha 1-\mathrm{P}_{2} \mathrm{~W}_{12} \mathrm{Mo5}_{5} \square$, the alcohol addition to ketone does not seem to influence the formation of AA, thus similar AA yields were obtained, respectively, with 46 and $30 \%$ from (-one) oxidation and 47 and $34 \%$ from (-ol)/(-one) mixture oxidation. While in the case of $\alpha 1-\mathrm{P}_{2} \mathrm{~W}_{12} \mathrm{Mo}_{5} \mathrm{Sn}$, $\mathrm{Cs}_{4} \mathrm{SnP}_{2} \mathrm{~W}_{12} \mathrm{Mo}_{6}$ and $\mathrm{Cs}_{3} \mathrm{SbP}_{2} \mathrm{~W}_{12} \mathrm{Mo}_{6}$, a strong decrease of AA yield from 33 to 17, 61 to 27, and 52 to $37 \%$ was observed, respectively after (-ol) addition to (-one) suggesting that the alcohol inhibits AA formation. This is can be attributed to the hydrogen bonds formation between the $\mathrm{C}=\mathrm{O}$ group of -one and the hydrogen of $\mathrm{C}-\mathrm{OH}$ group of -ol, that makes difficult the oxidation of both substrates. Results are in agreement with those observed in literature $[12,18-22]$.

The AA yield increases with oxidative power increase of POM, following sequence: $\mathrm{Cs}_{4} \mathrm{SnP}_{2} \mathrm{~W}_{12} \mathrm{Mo}_{6}>\mathrm{Cs}_{3} \mathrm{SbP}_{2} \mathrm{~W}_{12} \mathrm{Mo}_{6}>$ $\alpha-\mathrm{P}_{2} \mathrm{~W}_{12} \mathrm{Mo}_{6}>\alpha 1-\mathrm{P}_{2} \mathrm{~W}_{12} \mathrm{Mo5}_{5} \mathrm{Sn} \sim \alpha 1-\mathrm{P}_{2} \mathrm{~W}_{12} \mathrm{Mo}_{5} \square$ $>\alpha-\mathrm{H}_{6} \mathrm{P}_{2} \mathrm{Mo}_{6} \mathrm{~W}_{12}$. Therefore, these results show that the AA formation requires oxidative sites

Table 6. AA yield as function of POM composition with cyclohexene substrate

\begin{tabular}{lc}
\hline \multicolumn{1}{c}{ Catalysts } & $\begin{array}{c}\text { Adipic acid yields } \\
(\%)\end{array}$ \\
\hline$\alpha-\mathrm{P}_{2} \mathrm{~W}_{12} \mathrm{Mo}_{6}$ & 21 \\
$\alpha 1-\mathrm{P}_{2} \mathrm{~W}_{12} \mathrm{Mo}_{5} \square$ & 32 \\
$\alpha 1-\mathrm{P}_{2} \mathrm{~W}_{12} \mathrm{Mo5}_{5} \mathrm{Sn}$ & 23 \\
$\mathrm{Cs}_{4} \mathrm{SnP}_{2} \mathrm{~W}_{12} \mathrm{Mo}_{6}$ & 11 \\
$\mathrm{Cs}_{3} \mathrm{SbP}_{2} \mathrm{~W}_{12} \mathrm{Mo}_{6}$ & 30 \\
\hline
\end{tabular}

Reaction parameters: reaction temperature: $70^{\circ} \mathrm{C}$; reaction time: $20 \mathrm{~h}$; stirring: $1000 \mathrm{rpm} ; n_{\text {catalyst }} / n_{\text {-ene: }}$; $13.3 \times 10^{-4}$ and $6 \mathrm{~mL}$ of $\mathrm{H}_{2} \mathrm{O}_{2}(30 \%)$ added with 0.5 $\mathrm{mL} / \mathrm{h}$ flow rate using manual mode coming from the presence several redox couples as $\mathrm{Mo}(\mathrm{VI}) / \mathrm{Mo}(\mathrm{V}), \mathrm{Sn}(\mathrm{IV}) / \mathrm{Sn}(\mathrm{II})$, and $\mathrm{Sb}(\mathrm{V})$ / $\mathrm{Sb}$ (III) and different peroxo-POM species, resulting of hydrogen peroxide action on reduced POM.

\subsubsection{Cyclohexene oxidation}

The catalytic performances of POMs were examined in the cyclohexene oxidation to adipic acid in the same operation conditions than those used in the cyclohexanone oxidation. The reaction temperature was fixed at $70{ }^{\circ} \mathrm{C}$, temperature inferior to that of boiling point (83 $\left.{ }^{\circ} \mathrm{C}\right)$. The results of Table 6 show that the POMs are less active in cyclohexene oxidation to AA compared to those obtained from cyclohexanone oxidation with yields of 11-32 \% against 30-61\%. $\alpha 1-\mathrm{P}_{2} \mathrm{~W}_{12} \mathrm{Mo} \square$, and $\mathrm{Cs}_{3} \mathrm{SbP}_{2} \mathrm{~W}_{12} \mathrm{Mo}_{6}$ have a similar behaviour with 30 and $32 \%$ of AA yield, superior to those obtained with others catalysts (11-23\%).

Compared to the AA formation from cyclohexanone oxidation that requires of strong oxidative sites, in the case of cyclohexene oxidation, its formation seems to be independent oxidative character of POM. Therefore, a strong oxidative power not favored the cyclohexene oxidation to adipic acid.

The obtained AA yields in this study are inferior to those obtained by others authors with tungsten-based materials [46-52]. Whereas, they used several additives as phase transfer agent, surfactant-type catalysts, organic solvents, ionic liquid and mineral acids, harmful compounds.

\subsubsection{Reusability of the catalyst}

The catalytic performance of used POM catalyst was also evaluated in order to test its activity as well as its stability. The results are represented in Table 7. Each cycle

Table 7. AA yield (\%) obtained from cyclohexanone oxidation with fresh and used POM

\begin{tabular}{lcc}
\hline \multicolumn{1}{c}{$\mathrm{POM}$} & $\begin{array}{c}\text { AA yield (\%) } \\
\text { 1st }^{\text {sycle }}\end{array}$ & $\begin{array}{c}\text { AA yield }(\%) \\
2^{\text {nd }} \text { cycle }\end{array}$ \\
\hline$\alpha-\mathrm{P}_{2} \mathrm{~W}_{12} \mathrm{Mo}_{6}$ & 46 & 0 \\
$\mathrm{Cs}_{4} \mathrm{SnP}_{2} \mathrm{~W}_{12} \mathrm{Mo}_{6}$ & 61 & 0 \\
$\mathrm{Cs}_{3} \mathrm{SbP}_{2} \mathrm{~W}_{12} \mathrm{Mo}_{6}$ & 52 & 0 \\
\hline
\end{tabular}

Reaction parameters: reaction temperature: $90^{\circ} \mathrm{C}$, stirring: $1000 \mathrm{rpm}$; $n_{\text {catays }} / n_{\text {-one: }} 13.3 \times 10^{-4}$ and $6 \mathrm{~mL}$ of $\mathrm{H}_{2} \mathrm{O}_{2}(30 \%)$ added with $0.5 \mathrm{~mL} / \mathrm{h}$ flow rate using manual mode 
lasts $20 \mathrm{~h}$. After recovery of the adipic acid, 15 mmol of cyclohexanone were added to reaction mixture and the oxidation reaction was carried out with the soluble used catalyst, under the optimized conditions. Obtained AA yields after the first run are 46,61 , and $52 \%$ in the presence of $\alpha-\mathrm{P}_{2} \mathrm{~W}_{12} \mathrm{Mo}_{6}, \mathrm{Cs}_{4} \mathrm{SnP}_{2} \mathrm{~W}_{12} \mathrm{Mo}_{6}$, and $\mathrm{Cs}_{3} \mathrm{SbP}_{2} \mathrm{~W}_{12} \mathrm{Mo}_{6}$, respectively. When the test was repeated a second one with the same used catalyst, AA was not observed. These results seem to suggest a total deactivation of the catalyst.

\section{Conclusion}

In this work, the Dawson structure and purity of salt were confirmed by FT-IR and ${ }^{31} \mathrm{P}$ NMR spectroscopies, respectively, for potassium salts, $\alpha-\mathrm{K}_{6} \mathrm{P}_{2} \mathrm{~W}_{18} \mathrm{O}_{62}, \alpha-\mathrm{K}_{6} \mathrm{P}_{2} \mathrm{~W}_{12} \mathrm{Mo}_{6} \mathrm{O}_{62}, \quad \alpha-$ $\alpha 1-\mathrm{K}_{10} \mathrm{P}_{2} \mathrm{~W}_{12} \mathrm{Mo}_{5} \square \mathrm{O}_{61}, \alpha 1-\mathrm{K}_{8} \mathrm{P}_{2} \mathrm{~W}_{12} \mathrm{Mo}_{5} \mathrm{SnO}_{61}$ and cesium mixed salts, $\mathrm{Cs}_{4} \mathrm{SnP}_{2} \mathrm{~W}_{12} \mathrm{Mo}_{6} \mathrm{O}_{62}$, and $\mathrm{Cs}_{3} \mathrm{SbP}_{2} \mathrm{~W}_{12} \mathrm{Mo}_{6} \mathrm{O}_{62}$. The UV-Vis spectroscopy showed that tin and antimony based heteropolysalts were partially reduced. The XRD results evidenced the effect of Dawson polyoxometalate composition on its crystalline structure.

The operation conditions of the cyclohexanone oxidation in the presence of $30 \%$ hydrogen peroxide toward adipic acid were optimized. Among, the tested POMs, $\alpha-\mathrm{Cs}_{4} \mathrm{SnP}_{2} \mathrm{~W}_{12} \mathrm{Mo}_{6} \mathrm{O}_{62}$ and $\alpha-\mathrm{Cs}_{3} \mathrm{SbP}_{2} \mathrm{~W}_{12} \mathrm{Mo}_{6} \mathrm{O}_{62}$ exhibit the best catalytic performances with 61 and $52 \%$ of adipic acid yield, respectively. In the case of the cyclohexene oxidation, $\alpha 1-\mathrm{P}_{2} \mathrm{~W}_{12} \mathrm{Mo}_{5} \square$ and $\mathrm{Cs}_{3} \mathrm{SbP}_{2} \mathrm{~W}_{12} \mathrm{Mo}_{6}$ were found to be the most active with $30-32 \%$ of AA yield. The absence of additives as phase transfer agent, organic solvents and mineral acids, in this process makes the synthesis of adipic acid more environments respectful.

\section{Acknowledgement}

We thank the financial support by the Ministry of Higher Education and Scientific Research, Algeria.

\section{References}

[1] Li, G.X., Ding, Y., Wang, J.M., Suo, J. (2007). New progress of Keggin and Wells-Dawson type polyoxometalates catalyze acid and oxidative reactions. J. Mol. Catal. A: Chem., 262 (1-2): 67-76.

[2] Li, W.Y., Liu, Y.Y., Zheng, H.Y., Li, Z. (2010). Molecular structure and application of heteropolyacid (salt) catalysts for organic synthesis. Chemical Industry and Engineering Progress, 29 (2): 243-249.
[3] Bielański, A., Lubańska, A. (2004). FTIR investigation on Wells-Dawson and Keggin type heteropolyacids: Dehydration and ethanol sorption. J. Mol. Catal. A: Chem., 224(1-2): 179-187.

[4] Heravi, M.M., Sadjadi, S. (2009). Recent developments in use of heteropolyacids, their salts and polyoxometalates in organic synthesis. J. Iran. Chem. Soc., 6(1): 1-54.

[5] Cavani, F., Mezzogori, R., Trovarelli, A. (2003). The characterization and the catalytic activity of modified Wells-Dawson-type polyoxometalates in the oxidehydrogenation of isobutane to isobutene. J. Mol. Catal. A: Chem., 204-205(1): 599-607.

[6] Pozéniczek, J., Lubańska, A., Micek-Ilnicka, A., Mucha, D., Lalik, E., Bielański, A. (2006). $\mathrm{TiO}_{2}$ and $\mathrm{SiO}_{2}$ supported Wells-Dawson heteropolyacid $\mathrm{H}_{6} \mathrm{P}_{2} \mathrm{~W}_{18} \mathrm{O}_{62}$ as the catalyst for ETBE formation. Appl. Catal. A: Gen., 298: 217-224.

[7] Yu, J., Yang, P., Yang, Y., Wu, T., Parquette, J.R., (2006). Hydroxylation of phenol with hydrogen peroxide over tungstovanadophosphates with Dawson structure. Catal. Commun., 7(3): 153-156.

[8] Dermeche, L., Salhi, N., Hocine, S., Thouvenot, R., Rabia, C. (2012). Effective Dawson type polyoxometallate catalysts for methanol oxidation. J. Mol. Catal. A: Chem. 356: 29-35.

[9] Saher, L., Makhloufi-Chebli, M., Dermeche, L., Boutemeur-Khedis, B., Rabia, C., Silva, A.M.S., Hamdi, M. (2016). Keggin and Dawson-type polyoxometalates as efficient catalysts for the synthesis of 3,4dihydropyrimidinones: experimental and theoretical studies. Tetrahedron Letters. 57(13): 1492-1496.

[10] Mansuy, D., Bartoli, J.F., Battioni, P., Lyon, D.K., Finke, R.G. (1991). Highly oxidation resistant inorganic-porphyrin analogue polyoxometalate oxidation catalysts. Catalysis of olefin epoxidation and aliphatic and aromatic hydroxylations starting from $\alpha_{2}-\mathrm{P}_{2} \mathrm{~W}_{17} \mathrm{O}_{61}$ $\left(\mathrm{M}^{\mathrm{n}} \cdot \mathrm{Br}\right)^{(\mathrm{n}-11)}\left(\mathrm{M}^{\mathrm{n}+}=\mathrm{Mn}^{3+}, \mathrm{Fe}^{3+}, \mathrm{Co}^{2+}, \mathrm{Ni}^{2+}, \mathrm{Cu}^{2+}\right)$, including quantitative comparisons to metalloporphyrin catalysts. J. Am. Chem. Soc., 113(19): 7222-7226.

[11] Chen, D., Yang, X., Zhou, H., He, J. (2010). Green catalytic oxidation of cyclohexanone with $\mathrm{H}_{2} \mathrm{O}_{2}$ to adipic acid using a monovacant dawson heteropolytungstate a catalyst. Shiyou Huagong/Petrochemical Technology, 39(6): 656-660.

[12] Moudjahed, M., Dermeche, L., Benadji, S., Mazari, T., Rabia, C. (2016). Dawson-type polyoxometalates as green catalysts for adipic acid synthesis. J. Mol. Catal. A: Chem., 414: 72-77. 
[13] Briand, L.E., Baronetti, G.T., Thomas, H.J. (2003). The state of the art on Wells-Dawson heteropoly-compounds. A review of their properties and applications. Appl. Catal. A: Gen., 256(1-2): 37-50.

[14] Davis, D.D., Kemp, D.R. (1991). Adipic Acid, M. Howe-Grant (Ed.), In ECT, <https://doi.org/10.1002/cite.330641225>

[15] Castellan, A., Bart, J.C.J., Cavallaro, S. (1991). Synthesis of adipic acid via the nitric acid oxidation of cyclohexanol in a two-step batch process. Catal. Today., 9(3): 285-299.

[16] Castellan, A., Bart, J.C.J., Cavallaro, S. (1991). Nitric acid reaction of cyclohexanol to adipic acid. Catal. Today., 9(3): 255-283.

[17] Thiemens, M.H., Trogler, W.C. (1991). Nylon production: an unknown source of atmospheric nitrous oxide. Science, 251(4996): 932-934.

[18] Cavani, F., Ferroni, L., Frattini, A., Lucarelli, C., Mazzini, A., Raabova, K., Babini, P. (2011). Evidence for the presence of alternative mechanisms in the oxidation of cyclohexanone to adipic acid with oxygen, catalysed by Keggin polyoxometalates. Appl. Catal. A: Gen., 391(1-2): 118-124.

[19] Mazari, T., Benadji, S., Tahar, A., Dermeche, L., Rabia, C. (2013). Liquid-Phase Synthesis of Adipic Acid Using Keggin-Type Phosphomolybdates Catalysts. J. Mater. Sci. Eng. B., 3(3B): 146-151.

[20] Benadji, S., Mazari, T., Dermeche, L., Salhi, N., Cadot, E. Rabia, C. (2013). Clean Alternative for Adipic Acid Synthesis Via LiquidPhase Oxidation of Cyclohexanone and Cyclohexanol Over $\mathrm{H}_{3-2 \mathrm{x}} \mathrm{Co}_{\mathrm{x}} \mathrm{PMo}_{12} \mathrm{O}_{40}$ Catalysts with Hydrogen Peroxide. Catal. Lett., 143(8): 749-755.

[21] Tahar, A., Benadji, S., Mazari, T., Dermeche, L., Marchal-Roch, C., Rabia, C. (2015). Preparation, Characterization and Reactivity of Keggin Type Phosphomolybdates, $\mathrm{H}_{3-2 \mathrm{x}} \mathrm{Ni}_{\mathrm{x}} \mathrm{PMo}_{12} \mathrm{O}_{40}$ and $\left(\mathrm{NH}_{4}\right)_{3-2 \mathrm{x}} \mathrm{Ni}_{\mathrm{x}} \mathrm{PMo}_{12} \mathrm{O}_{40}$, for Adipic Acid Synthesis. Catal. Lett., 145(2): 569-575.

[22] Mouheb, L., Dermeche, L., Mazari, T., Benadji, S., Essayem, N., Rabia, C. (2018). Clean Adipic Acid Synthesis from LiquidPhase Oxidation of Cyclohexanone and Cyclohexanol Using $\left(\mathrm{NH}_{4}\right)_{\mathrm{x}} \mathrm{A}_{\mathrm{y}} \mathrm{PMo}_{12} \mathrm{O}_{40}(\mathrm{~A}: \mathrm{Sb}, \mathrm{Sn}$, Bi) Mixed Heteropolysalts and Hydrogen Peroxide in Free Solvent. Catal. Lett., 148(2): 612-620.

[23] Chavan, S.A., Srinivas, D., Ratnasamy, P. (2002). Oxidation of cyclohexane, cyclohexanone, and cyclohexanol to adipic acid by a non- $\mathrm{HNO}_{3}$ route over $\mathrm{Co} / \mathrm{Mn}$ cluster complexes. J. Catal., 212(1): 39-45.
[24] Iwahama, T., Syojyo, K., Sakaguchi, S. Ishii, Y. (1998). Direct conversion of cyclohexane into adipic acid with molecular oxygen catalyzed by N-hydroxyphthalimide combined with $\mathrm{Mn}(\mathrm{acac})_{2}$ and $\mathrm{Co}(\mathrm{OAc})_{2}$. Org. Proc. Res. Dev., 2(4): 255-260.

[25] Bonnet, D., Ireland, T., Fache, E. Simonato, J.P. (2006). Innovative direct synthesis of adipic acid by air oxidation of cyclohexane. Green Chem., 8(6): 556-559.

[26] Lü, H., Ren, W., Liu, P., Qi, S., Wang, W., Feng, Y., Wang, Y. (2012). One-step aerobic oxidation of cyclohexane to adipic acid using an Anderson-type catalyst $\left[\left(\mathrm{C}_{18} \mathrm{H}_{37}\right)_{2} \quad \mathrm{~N}\right.$ $\left.\left(\mathrm{CH}_{3}\right)_{2}\right]_{6} \mathrm{Mo}_{7} \mathrm{O}_{24}$. Appl. Catal. A: Gen., 441442(1): 136-141.

[27] Nomiya, K., Miwa, M., Sugaya, Y. (1984). Catalysis by heteropolyacid-VII. Catalytic oxidation of cyclohexanol by dodecamolybdate. Polyhedron, 3(5): 607-610.

[28] Contant, R., Abbessi, M., Thouvenot, R. Hervé, G. (2004). Dawson Type Heteropolyanions. 3. Syntheses and ${ }^{31} \mathrm{P}, 51 \mathrm{~V}$, and ${ }^{183} \mathrm{~W}$ NMR Structural Investigation of Octadeca (molybdo- tungsto-vanado) diphosphates Related to the $\left[\mathrm{H}_{2} \mathrm{P}_{2} \mathrm{~W}_{12} \mathrm{O}_{48}\right]^{12-A n i o n . ~ I n o r g . ~}$ Chem., 43(12): 3597-3604.

[29] Mbomekalle, I.M., Lu, Y.W., Keita, B., Nadjo, L. (2004). Simple, high yield and reagentsaving synthesis of pure $\alpha$ $\mathrm{K}_{6} \mathrm{P}_{2} \mathrm{~W}_{18} \mathrm{O}_{62 .} 14 \mathrm{H}_{2} \mathrm{O}$. Inorg. Chem. Commun., 7(1): 86-90.

[30] Contant, R., Klemperer, W.G., Yaghi, O. (2007). Potassium octadecatungstodiphosphates $(\mathrm{V})$ and related lacunary compounds. Inorg. Synth., 27: 104-111.

[31] Contant, R., Ciabrini, J.P. (1981). Stereospecific preparations of new n-molybdo-(18-n)tungsto-2-phosphates and related "defect" compounds ( $\mathrm{n}=2,4$ or 5). J. Inorg. Nucl. Chem., 43(7): 1525-1528.

[32] Lyon, D.K., Miller, W.K., Novet, T., Domaille, P.J., Evitt, E., Johnson, D.C. Finke, R.G. (1991). Highly oxidation resistant inorganicporphyrin analog polyoxometalate oxidation catalysts. The Synthesis and Characterization of Aqueous-Soluble Potassium Salts of $\alpha_{2}-\mathrm{P}_{2} \mathrm{~W}_{17} \mathrm{O}_{61}\left(\mathrm{M}^{\mathrm{n}+} \cdot \mathrm{OH}_{2}\right)(\mathrm{n}-10)$ and Organic Solvent Soluble Tetra-n-butylammonium Salts of $\alpha_{2}-\mathrm{P}_{2} \mathrm{~W}_{17} \mathrm{O}_{61}\left(\mathrm{M}^{\mathrm{n}}+\mathrm{Br}\right)^{(\mathrm{n}-11)} \quad(\mathrm{M}=$ $\left.\mathrm{Mn}^{3+}, \mathrm{Fe}^{3+}, \mathrm{Co}^{2+}, \mathrm{Ni}^{2+}, \mathrm{Cu}^{2+}\right)$ ". J. Am. Chem. Soc., 113(19): 7209-7221.

[33] Rocchiccioli-Deltcheff, C. Thouvenot, R. (1979). Vibrational Studies of Heteropolyanions Related to $\alpha-\mathrm{P}_{2} \mathrm{~W}_{18} \mathrm{O}_{62}{ }^{6-}$ I-Infrared Evidence of the Structure of $\alpha_{1}$ and $\alpha_{2}$ $\mathrm{P}_{2} \mathrm{~W}_{17} \mathrm{O}_{61}{ }^{10-}$. Spectrosc. Lett., 12(2): 127-138. 
[34] Randall, W.J. (1996). The preparation of potassium salt of the Wells-Dawson type heteropolyacid. Inorg. Synth., 31: 177

[35] Harmalker, S.P., Leparulo, M.A., Pope, M.T. (1983). Mixed-valence chemistry of adjacent vanadium centers in heteropolytungstate anions. I. Synthesis and electronic structures of mono-, di-, and trisubstituted derivatives of. alpha.-octadecatungstodiphosphate (6-) ion (alpha.- $\left[\mathrm{P}_{2} \mathrm{~W}_{18} \mathrm{O}_{62}\right]^{6}$ ). J. Am. Chem. Soc., 105(13): 4286-4292.

[36] Fournier, M., Louis, C., Che, M., Chaquin, P. Masure, D. (1989). Polyoxometallates as models for oxide catalysts: Part I. An UV-visible reflectance study of polyoxomolybdates: Influence of polyhedra arrangement on the electronic transitions and comparison with supported molybdenum catalysts. $J$. Catal., 119(2): 400-414.

[37] Cavani, F., Mezzogori, R., Pigamo, A., Trifirò, F. Etienne, E. (2001). Main aspects of the selective oxidation of isobutane to methacrylic acid catalyzed by Keggin-type polyoxometalates. Catal. Today., 71(1-2): 97-110.

[38] Cavani, F., Mezzogori, R., Pigamo, A. Trifiro, F. (2001). Improved catalytic performance of Keggin-type polyoxometalates in the oxidation of isobutane to methacrylic acid under hydrocarbon-lean conditions using antimonydoped catalysts. Chem. Eng. J., 82(1-3): 33-42.

[39] Mazari, T., Marchal, C.R., Hocine, S., Salhi, N. Rabia, C. (2009). Oxidation of propane over substituted Keggin phosphomolybdate salts. J. Nat. Gas. Chem., 18(3): 319-324.

[40] Dermeche, L., Thouvenot, R., Hocine, S. Rabia, C. (2009). Preparation and characterization of mixed ammonium salts of Keggin phosphomolybdate. Inorg. Chim. Acta., 362(11): 3896-3900.

[41] Mazari, T., Marchal, C.R., Hocine, S., Salhi, N. Rabia, C. (2010). Oxidation of propane over ammonium-transition metal mixed keggin phosphomolybdate salts. J. Nat. Gas. Chem., 19(1): 54-60.

[42] Cabello, C.I., Botto, I.L. Thomas, H.J. (2000). Anderson type heteropolyoxomolybdates in catalysis $1 .\left(\mathrm{NH}_{4}\right)_{3}\left[\mathrm{CoMo}_{6} \mathrm{O}_{24} \mathrm{H}_{6}\right] \cdot 7 \mathrm{H}_{2} \mathrm{O} / \gamma$ $\mathrm{Al}_{2} \mathrm{O}_{3}$ as alternative of $\mathrm{Co}-\mathrm{Mo} / \gamma$ $\mathrm{Al}_{2} \mathrm{O}_{3}$ hydrotreating catalysts. Appl. Catal. A: Gen., 197(1): 79-86.
[43] Dawson, B. (1953). The Structure of the 9(18)- Heteropoly Anion in Potassium 9(18)Tungstophosphate, $\mathrm{K}_{6}\left(\mathrm{P}_{2} \mathrm{~W}_{18} \mathrm{O}_{62}\right)$. $14\left(\mathrm{H}_{2} \mathrm{O}\right)$. Acta. Cryst., 6: 113-126.

[44] Comuzzi, C., Dolcetti, G., Trovarelli, A., Cavani, F., Trifirò, F., Llorca, J., Finke, R.G. (1996). The solid-state rearrangement of the Wells-Dawson $\mathrm{K}_{6} \mathrm{P}_{2} \mathrm{~W}_{18} \mathrm{O}_{62 .} 10 \mathrm{H}_{2} \mathrm{O}$ to a stable Keggin-type heteropolyanion phase: a catalyst for the selective oxidation of isobutane to isobutene. Catal. Lett., 36(1-2): 75-79.

[45] Comuzzi, C., Primavera, A., Trovarelli, A., Bini, G., Cavani, F. (1996). Thermal stability and catalytic properties of the Wells-Dawson $\mathrm{K}_{6} \mathrm{P}_{2} \mathrm{~W}_{18} \mathrm{O}_{62} .10 \mathrm{H}_{2} \mathrm{O}$ heteropoly compound in the oxidative dehydrogenation of isobutane to isobutene. Top Catal., 3(3-4): 387-406.

[46] Fujitani, T., Nakazawa, M. (1988). A process for the preparation of carboxylic acid. Japanese Patent. 63-093746.

[47] Goyal, R., Sameer, S., Sarkar, B., Bag, A., Singhal, N. Bordoloi, A. (2017). Synthesis of

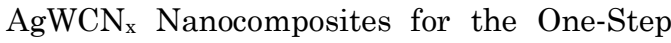
Conversion of Cyclohexene to Adipic Acid and Its Mechanistic Studies. Chem. Eur. J., 23(65): 16555-16565.

[48] Wang, X.Y., Miao, Y.X., Jia, Q., Su, Y.L., Cao, S.X. Dai, X.M. (2003). Study on the effect of solution acidity on the green synthesis of adipic acid. Petrochem. Tech., 32(7): 608-610.

[49] Jin, P., Zhao, Z., Dai, Z., Wei, D., Tang, M. Wang, X. (2011). Influence of reaction conditions on product distribution in the green oxidation of cyclohexene to adipic acid with hydrogen peroxide. Catal. Today., 175(1): 619624.

[50] Zhu, W., Li, H., He, X., Zhang, Q., Shu, H. Yan, Y. (2008). Synthesis of adipic acid catalyzed by surfactant-type peroxotungstates and peroxomolybdates. Catal. Commun., 9(4): 551-555.

[51] Shang, M., Noël, T., Wang, Q., Su, Y., Miyabayashi, K., Hessel, V., Hasebe, S. (2015). 2-and 3-Stage temperature ramping for the direct synthesis of adipic acid in micro-flow packed-bed reactors. Chem. Eng. J., 260: 454-462.

[52] Sato, K., Aoki, M., Noyori, R.A. (1998). Green route to adipic acid: Direct oxidation of cyclohexenes with 30 percent hydrogen peroxide. Science, 281(5383): 1646-1647. 